\title{
$O$ reuso do resíduo de gesso
}

Daniel Tavares Ferreira, Hualley Sanches Veludo, Marco Antônio de Oliveira, Rodrigo Santos de Castro, Wesley Rodrigues Borges, Carolina Oliveira Pinto

Universidade de Uberaba (UNIUBE)

rodrigosantosdecastro@gmail.comecarolina.pinto@uniube.br

\section{1 - Introdução}

O gesso é um importante recurso construtivo utilizado nos principais projetos estruturais, é de suma importância observar que por meio desse material é possível viabilizar propostas de acabamento, bem como em revestimentos ou até mesmo isolamentos.

Nas últimas décadas, a Engenharia alcançou importantes resultados em relação ao uso de tecnologias mais modernas e eficientes, do ponto de vista técnico. Embora, novas construções sejam construídas, ainda não existam medidas realmente práticas no que se refere ao descarte do gesso, proveniente das obras edificadas.

Este trabalho propõe-se a estudar e analisar possíveis medidas de reutilização do gesso proveniente de resíduos da construção civil.

\section{2 - Materiais e métodos}

Além de pesquisar a constituição adequada do gesso, no uso em obras, este trabalho propõe-se a relacionar as melhores medidas relacionadas ao descarte e reutilização desse material. Esse projeto pretende investigar analiticamente a bibliográfica específica sobre esse assunto, revisando conceitos e a literatura utilizada nos projetos de estruturas. De acordo com JOHN e ANTUNES (2002) há um amplo uso do gesso em atividades relacionadas com a construção civil, mas falta ainda ponderar as referências básicas sobre 0 assunto em relação ao descarte, ou ao uso dos resíduos (CONAMA).

\section{3 - Resultados e discussão}

Os principais resultados evidenciam uma carência de pesquisas em relação ao assunto, o que deixa em evidência sua relevância. Além disso, há uma necessidade de estudar o assunto, não apenas pelas exigências modernas de construção, sobretudo, por uma urgência ecológica.
Em matéria pública em 2013, o portal "Conexão Plastilit" apresenta por meio de uma entrevista com engenharia civil Sayonara Moraes Pinheiro a necessidade de manter uma gestão dos resíduos de uma obra e, principalmente, um núcleo avançado de pesquisas de acompanhamento e desenvolvimento sustentável de obra.

A sustentabilidade tem sido defendida há muito tempo, uma vez que o ser humano tem degradado importantes recursos naturais, 0 que - em pouco tempo - resultará em um colapso, caso nada seja feito no que concerne às essas questões.

Consoante Cavalcanti e Miranda (2011), o gesso pode ser utilizado em inúmeras situações, inclusive (quando reprocessado) na gestão ambiental de recursos naturais.

\section{4 - Considerações finais}

Ainda não se viabilizaram métodos práticos para se dar um destino ecologicamente adequado e viável comercialmente para o resíduo do gesso. É necessário conceber uma prática ao mesmo tempo sustentável, bem como viável, do ponto de vista comercial. Possibilitando, desse modo, a constituição de ferramentas adequadas para o uso do gesso em outras possibilidades construtivas.

\section{5 - Referências}

- CONAMA. Resolução no 307, de 05 de julho de 2002 . Estabelece diretrizes, critérios e procedimentos para a gestão dos resíduos da construção civil. Diário Oficial da República Federativa do Brasil, Brasília, DF, no 136, 17 de julho de 2002. Seção 1, p. 95-96.

. Resolução no 431, de 24 de maio de

2011. Altera o art. $3^{\circ}$ da Resolução $n^{\circ}$ 307, de 5 de julho de 2002, do Conselho Nacional do Meio Ambiente- CONAMA, estabelecendo nova classificação para o gesso. Diário Oficial da República Federativa do Brasil, Brasília, DF, no 99, 25 de maio de 2011. Seção 1, p. 123. 
8을 EnTec - Encontro de Tecnologia da UNIUBE / 28 a 30 de outubro de 2014 CAVALCANTI, C.F.B.; MIRANDA, A.C.P.

Estudos sobre alternativas para gestão

dos resíduos de gesso oriundos da

construção civil. Disponível em:

$<$ http://www.cesumar.br/prppge/pesquisa/epcc

2011/anais/claudio_felipe_boer_cavalcante.pd f>. Acessado em 8 de setembro de 2014.

CONEXÃO PLASTILIT. Gesso, do lixo civil direto para o desenvolvimento de novos produtos. Disponível em:

<http://plastilit.com.br/conexao/gesso-do-lixocivil-direto-para-o-desenvolvimento-de-novosprodutos/>. Acessado em 8 de setembro de 2014.

JOHN, V. M.; ANTUNES, R. P. N. Argamassas de gesso. Disponível em: $<$ http://seer.ufrgs.br/ambienteconstruido/articl e/view/3409/1823>. Acessado em 8 de setembro de 2014. 